\title{
Development of Moodle-based Physical Education Learning Media in Junior High Schools During the Pandemic
}

\author{
Ardiyan Naafi Hafizh Haaq1, Asep Bayu Dani Nandiyanto, ${ }^{2 *}$, Tedi Kurniawan, \\ Muhammad Roil Bilad ${ }^{4}$ \\ ${ }^{1}$ Departemen Pendidikan Kesehatan dan Rekreasi, Universitas Pendidikan Indonesia, Indonesia \\ ${ }^{2}$ Departemen Pendidikan Kimia, Universitas Pendidikan Indonesia, Indonesia \\ ${ }^{3}$ Community College of Qatar, Qatar \\ ${ }^{4}$ Faculty of Integrated Technologies, Universiti Brunei Darussalam, Brunei Darussalam \\ *Corresponding author : nandiyanto@upi.edu
}

\begin{abstract}
Abstrak: Terjadinya pandemi COVID-19 berdampak besar terhadap pendidikan di Indonesia. Berbagai upaya dilakukan untuk menarik minat belajar siswa, salah satu upaya yang dilakukan guru adalah media pembelajaran dengan tujuan agar siswa mampu memahami pelajaran. Oleh karena itu, perlu adanya ide baru untuk meningkatkan kualitas pendidikan di masa pandemi ini. Tujuan dari kegiatan ini adalah untuk mengetahui keefektifan aplikasi media pembelajaran Moodle sebagai sarana pembelajaran olahraga bagi siswa SMP pada masa pandemi, Setelah melihat hasil kegiatan di atas maka perlu adanya pembelajaran yang variatif untuk meningkatkan tingkat literasi siswa. Hasil penelitian ini menunjukkan peningkatan pengetahuan siswa pada saat post-test $68 \%$ meningkat menjadi $88 \%$ setelah data post-test diperoleh.
\end{abstract}

Keywords: Moodle, pendidikan jasmani, pandemi

\begin{abstract}
The occurrence of the COVID-19 pandemic has had a major impact on education in Indonesia. Various efforts were made to attract students' interest in learning, one of the efforts made by the teacher was learning media with the aim that students were able to understand the lesson. Therefore, there is a need for a new idea to improve the quality of education during this pandemic. The purpose of this study was to determine the effectiveness of the Moodle learning media application as a means of learning sports for junior high school students during a pandemic. After seeing the results of the activities above, it is necessary to have varied learning to increase the literacy level of students. The results of this study showed an increase in students' knowledge at the time of the post-test $68 \%$ increased to $88 \%$ after the post-test data was obtained.
\end{abstract}

Keywords: Moodle, physical education, pandemic

\section{Introduction}

Physical education, sports, and health are educational processes that utilize physical activity to acquire individual abilities, both physically, mentally, and emotionally, to train locomotor, non-locomotor, and manipulative basic movements. This understanding of physical education in sports and health does not refer to the traditional understanding which

Volume 3, Nomor 1, Maret 2022 | 38

Development of Moodle-based Physical Education Learning Media in Junior High Schools

During the Pandemic

Ardiyan Naafi Hafizh Haaq, Asep Bayu Dani Nandiyanto, Tedi Kurniawan, Muhammad Roil Bilad

https://doi.org/10.26874/jakw.v3i1.149 
assumes that physical education comes from physical activity, but it must be understood that physical education is sport and health as a process of character building, quality of thinking and children. Development. Physical education is also an effort to learn by using large muscle activity so that the learning process that takes place is not hampered by health problems and the growth of children's bodies in elementary school. Effectiveness is the main element to achieve the goals or objectives that have been determined in each organization, activity or program. It is said to be effective if the goals or objectives are achieved as determined. Effectiveness is a measure in terms of achieving predetermined goals. Effectiveness means successful or appropriate. Effective is a basic word, while the adjective effective is effective (Wicaksana E, 2021).

Moodle is the most popular open source program among existing e-learning programs, such as atutor, Learning Management System (LMS) and so on (Amiroh. 2012). This Moodle application was first developed by Martin Dougiamas in August 2002 with Moodle version 1.0. Moodle is an acronym for Modulator Object Oriented Dynamic Learning Environment which teaches and students carry out teaching activities in online activities (Hakim, A. R. 2018).

The use of this Moodle application is very helpful, especially in the midst of this andemic covid-19 situation which requires social distancing, so this Moodle application can be used as a solution so that teaching and learning activities continue as they should. With this application, it is endemic for teachers to continue to be able to share their knowledge without having to violate the obligation to keep their distance, and students also get their right to get knowledge (Samala, et al 2019). With this application, it proves that distance does not hinder something, especially in the field of andemic n. By using this e-learning-based application, the long distance between teachers and students during andemic covid can be helped because of the teaching team. There are features that can help during the learning process, such as quizzes, collaboration, assignments and communication and which can upload various forms of material provided are called main features (Haqien and Rahman, 2020).

When the Covid-19 pandemic condition is like today, it can affect all aspects or activities in human life, in the economy or in a pandemic. (Hartanti et al., 2021). In fact, at this time with the COVID-19 pandemic encouraging all pandemic pandemics to conduct online learning, even with positive academic results, however, students reported an increase in 
pandemics, anxiety and also difficulty concentrating because they were not used to it (Lemay et al., 2021). Therefore, it is suitable to be used as a learning medium (Haqien \& Rahman, 2020; Friday, 2021). On March 2, 2020, the first case of Covid-19 was found in Indonesia in 31-year-old and 64-year-old women who are both a child and a parent (Dyah, 2020). This is a problem that has caused more than 200 countries in the world, including Indonesia, to suppress its spread by implementing a lockdown, improving health services, including the availability of personal protective equipment (PPE) and notification of Stay At Home. Indonesia itself has been heavily affected by COVID-19 with a case fatality rate (CFR) of 8.9\% at the end of March 2020 (Setiati \& Azwar, 2020).

\section{Method}

This activity is a quantitative descriptive study using a survey method conducted online. In this study, we used Simple Random Sampling, where Simple Random Sampling is said to be simple (simple) because sample members from the population were taken randomly without regard to the existing strata in the population, The sample in this study were 7 th grade students of Junior High School with a total of 10 students as respondents from a total population of 10 students (Juita \& Yusmaridi, 2018).

\section{Results and Discussion}

Table 1 show the responses that have been collected from class VII students as many as 10 people. The number of samples includes $80 \%$ for male students and $20 \%$ for female students. This activity was conducted online and the media used to collect pre-test and posttest data was google form. The results show several discussion points :

i. From question no 1 it was found that all students know what sport is

ii. From question no 2, it was found that all students know that exercise can make the body healthy

iii. From question no 3 the students got $20 \%$ better results on what is warm-up in sports

iv. From question no 4 the students got $20 \%$ better results on what is relaxation in sports

v. From question no 5 the students get $30 \%$ better results regarding warm-up, we are prone to injury

vi. From question no. 6 the students got $30 \%$ better results regarding the factor of body aches during exercise because they did not relax after exercising. 
vii. From question no 7 the students got $30 \%$ better results regarding that exercise can improve mood

viii. From question no 8 the students got $20 \%$ better results regarding that exercise can increase self-confidence

ix. From question no 9 the students got $20 \%$ better results regarding that by exercising can relieve stress

x. From question no 10 the students got $20 \%$ better results regarding that by exercising you can lose fat in the body

Table 1. Pre-test and post-test result.

\begin{tabular}{lllll}
\hline No & \multicolumn{1}{c}{ Questions } & Pre-test & Post-test & Gain \\
1 & Do you know what sport is ? & $100 \%$ & $100 \%$ & $0 \%$ \\
2 & Can exercise make our body healthy? & $100 \%$ & $100 \%$ & $0 \%$ \\
3 & Do you know what a warm-up in sports is ? & $80 \%$ & $100 \%$ & $20 \%$ \\
4 & Do you know what relaxation is in sports ? & $70 \%$ & $90 \%$ & $20 \%$ \\
5 & Can warming up prevent us from getting & $60 \%$ & $90 \%$ & $30 \%$ \\
& injured ? & & & \\
6 & Is the occurrence of aches in the body caused & $50 \%$ & $80 \%$ & $30 \%$ \\
& by not relaxing? & & & \\
7 & Can exercising improve your mood ? & $50 \%$ & $80 \%$ & $30 \%$ \\
8 & Can exercise increase self-confidence ? & $50 \%$ & $70 \%$ & $20 \%$ \\
9 & Can exercise deal with stress ? & $60 \%$ & $80 \%$ & $20 \%$ \\
10 & Can exercise lose fat in the body? & $70 \%$ & $90 \%$ & $20 \%$ \\
\hline
\end{tabular}

From the Table 1, it was obtained that $68 \%$ of the pre-test results of students' knowledge about sports knowledge were given, but after being given an explanation of the material through the Moodle learning media application, the students' post-test results increased to $88 \%$, the use of Moodle learning media was able to have a positive impact on development of student literacy.

\section{Conclusion}

Based on the results of this study, there needs to be varied learning methods to improve student literacy levels. The results showed an increase in students' knowledge at the time of post-test increased to $88 \%$ after post-test data was obtained. Different methods are able to develop children's literacy. After seeing the results of the activities above, it is necessary to 
have varied learning to increase the literacy level of students. The results of this study showed an increase in students' knowledge at the time of the post-test $68 \%$ increased to $88 \%$ after the post-test data was obtained. Various methods are able to develop children's literacy, one of which is by presenting material through Moodle learning applications that make it easier for students to learn.

\section{Acknowledgement}

We acknowledged Bangdos, Universitas Pendidikan Indonesia. We thank Toto, S.Pd from Junior High School 2 Banjaran. This study is a part of Community Service Program Tematik Literasi 2021 from group 21 Lembaga Penelitian dan Pengabdian Masyarakat (LPPM), Universitas Pendidikan Indonesia. We also thank to Kantor Jurnal and Publikasi, Directorate of International Affairs, Universitas Pendidikan Indonesia. We thank to Nissa Nur Azizah, Dwi Fitria Al Hussaeni, S.T., M.Eng., Muktiarni, S.Pd., M.Pd., Rina Maryanti, S.Pd., M.Pd., and Asri Wibawa Sakti, M.Pd.

\section{References}

Amiroh. 2012. Membangun E-learning Dengan Learning Management System Moodle, PT Berkah Mandiri Global Indo. Sidoarjo.

Dyah, P. S. 2020. Efektivitas pembelajaran jarak jauh dengan daring selama pandemi covid19 mata pelajaran pendidikan jasmani olahraga dan kesehatan (PJOK). Pendidikan Jasmani Olahraga dan Kesehatan, 1(1), 1-11.

Hakim, A. R. 2018. Pengembangan E-Learning Berbasis Moodle Sebagai Media Pengelolaan Pembelajaran. Kodifikasia, 12(2), 167-183.

Haqien, D. \& Rahman, A. A. 2020. Pemanfaatan zoom meeting untuk proses pembelajaran pada masa pandemi covid-19. SAP (Susunan Artikel Pendidikan), 5(1), 51-56.

Juita, D. \& Yusmaridi, Y. 2018. Pengaruh kegiatan kuliah umum terhadap peningkatan pemahaman konsep metodologi penelitian mahasiswa semester 7 jurusan tadris biologi ftik iain kerinci. Tarbawi: Jurnal Ilmu Pendidikan, 14(2), 45-50.

Lemay, D.J., Bazelais, P. \& Doleck, T. 2021. Transition to online learning during the covid19 pandemic. Computers in Human Behavior Reports, 4, 100130.

Samala, A. D., Fajri, B. R., \& Ranuharja, F. 2019. Desain Dan Implementasi Media Pembelajaran Berbasis Mobile Learning Menggunakan Moodle Mobile App. Jurnal Teknologi Informasi Dan Pendidikan, 12(2), 13-20.

Volume 3, Nomor 1, Maret 2022 | 42

Development of Moodle-based Physical Education Learning Media in Junior High Schools

During the Pandemic

Ardiyan Naafi Hafizh Haaq, Asep Bayu Dani Nandiyanto, Tedi Kurniawan, Muhammad Roil Bilad

https://doi.org/10.26874/jakw.v3i1.149 
Setiati, S., and Azwar, M.K. 2020. Covid-19 and Indonesia. Acta Medica Indonesiana, 52(1), 84-89.

Surahni, S. 2017. Pendidikan jasmani, olahraga, dan kesehatan (PJOK) sebagai sarana pendidikan moral. Urecol, 1(1), 39-46.

Wicaksana, E. 2020. Efektifitas Pembelajaran Menggunakan Moodle Terhadap Motivasi Dan Minat Bakat Peserta Didik Di Tengah Pandemi Covid-19. EduTeach: Jurnal Edukasi Dan Teknologi Pembelajaran, 1(2), 117-124. 